\title{
Sigma: Journal of Political and International Studies
}

$1-1-2006$

\section{Education Inequality in the Republic of Korea: Measurement and Causes}

Matthew Burt

Follow this and additional works at: https://scholarsarchive.byu.edu/sigma

\section{Recommended Citation}

Burt, Matthew (2006) "Education Inequality in the Republic of Korea: Measurement and Causes," Sigma: Journal of Political and International Studies: Vol. 24 , Article 2.

Available at: https://scholarsarchive.byu.edu/sigma/vol24/iss1/2

This Article is brought to you for free and open access by the Journals at BYU ScholarsArchive. It has been accepted for inclusion in Sigma: Journal of Political and International Studies by an authorized editor of BYU ScholarsArchive. For more information, please contact scholarsarchive@byu.edu, ellen_amatangelo@byu.edu. 


\section{EDUCATION INEQUALITY IN THE REPUBLIC OF KOREA: Measurement and Causes}

\section{MATTHEW BURT}

\section{INTRODUCTION}

The Republic of (South) Korea is one of relatively few developing states to have experienced consistent, significant success in economic, social, and governmental development. Although it began its post-civil war history with a real gross domestic product (GDP) per capita of about $\$ 1,459$ in 1955 , South Korea is now considered a high-income country by the World Bank with a per capita income of $\$ 15,876$. With the exception of the 1980 recession and the 1997 Asian financial crisis, South Korea has maintained some of the highest GDP growth rates in the world for the past forty-five years (see Table 1). Today it is a global leader in industries ranging from shipbuilding to cellular phones and stem-cell research. The country has likewise experienced remarkable improvements in key indicators such as life expectancy, infant mortality, and education attainment. In addition, although the country was controlled by authoritarian governments from its establishment in 1948 up to the late 1980 s and during its most extraordinary periods of economic growth, South Korea today is considered a politically stable, liberal democracy.

Table 1: Key Economic Indicators of South Korea

\begin{tabular}{|c|c|c|c|c|}
\hline Year & $\begin{array}{c}\text { Population } \\
\text { (in 100s) }\end{array}$ & $\begin{array}{c}\text { Savings (\% } \\
\text { in current } \\
\text { prices) }\end{array}$ & $\begin{array}{c}\text { GDP/Cap. } \\
\text { (constant 1996 } \\
\text { \$US) }\end{array}$ & $\begin{array}{c}\text { GDP/Cap. } \\
\text { Growth } \\
\text { Rate (\%) }\end{array}$ \\
\hline 1955 & 21674 & 3.98 & 1458.67 & 8.05 \\
\hline 1960 & 25252 & 1.06 & 1495.24 & -1.15 \\
\hline 1965 & 28814 & 7.33 & 1802.65 & 2.67 \\
\hline 1970 & 32241 & 13.86 & 2715.58 & 5.9 \\
\hline 1975 & 35281 & 19.74 & 3656.55 & 4.44 \\
\hline 1980 & 38124 & 25.82 & 4789.83 & -4.88 \\
\hline 1985 & 40806 & 34.03 & 6568.89 & 5.33 \\
\hline 1990 & 42869 & 37.91 & 9952.39 & 8.3 \\
\hline 1995 & 45093 & 39.03 & 13551.57 & 7.69 \\
\hline 2000 & 47275 & 33.56 & 15875.84 & 7.2 \\
\hline
\end{tabular}

Source: Heston, Summers, \& Aten, 2002 


\section{Burt - Korean Education}

Although its development experience was facilitated by cultural, geographical. and historical contexts that cannot be duplicated in today"s developing countries. South Korea provides many insights into the question that state leaders, economists, humanitarians. and development experts have struggled with for decades: why are some countries rich and others poor? General explanations for South Korea's success include: effective government policies, high rates of saving, a relatively egalitarian distribution of income. large infusions of foreign aid. and East Asian. Confucian values that emphasizes thrift. diligence, and discipline (Weil, 2005, p. 347). A key piece in South Korea's development puzzle is the dramatic improvement in human capital through mass education (McGinn et al., 1980; Morris, 1996; Lopez et al.. 1998). This contrasts with the experience of most developing countries, where investments in education have not reached expectations (Holsinger, 2005; Pritchett, 2001); several scholars have suggested this may be due to levels of inequality in the distribution of education (Holsinger, 2005; Lopez et al., 1998; Thomas et al., 2001; Dessus, 2001).

To test this proposition, I will use the education Gini coefficient to analyze the distribution of human capital in South Korea from 1970 to 2000. The aggregate, national level of education inequality as measured by the Gini coefficient has fallen significantly over the past thirty years (see Figure 1). This paper will identify the patterns of education inequality across South Korea's administrative divisions from 1970 to 2000 ; it will then trace the development of South Korea's education system and suggest possible causes for the rapid decline in education inequality that occurred in all areas of the country and thus provide an example of success that can be used by policymakers in other developing countries struggling with the problem of education inequality.

\section{DEVELOPMENT OF THE SOUTH KOREAN EDUCATION SYSTEM}

The people of this country are very enthusiastic about [education] and the method they use is gentle and ingenious. Teachers offer their students the teaching of earlier scholars and constantly cite the example of those who attained fame through high scholarship. The boys devote their time to study day and night (Choe, 1987).

... the tragedy of higher education in Korea is not in the lack of textbooks, laboratory equipment, or even faculty; the real tragedy is in the lack of realization on the part of both students and staff that no education is taking place under present conditions (Kehoe, 1949).

Education has been one of the major sources of economic growth and social development in Korea. In three decades, Korea has been able to accomplish nearly 100 percent coverage for primary and secondary education. Moreover, Korea now has a tertiary education sector that is as large as those in developed countries (Kim, 2002).

The statements above were made. respectively, by a shipwrecked Dutch merchant from the seventeenth century (in the first Western account of Korea), an educational 


\section{Burt - Korean Education}

specialist in the U.S. War Department in the 1940s, and an education specialist from the World Bank in 2002. These widely varying statements likely have much to do with individual perceptions, but they are indicative of the extreme changes, both positive and negative. the South Korean education system has undergone in the last century. This section will examine developments in the South Korean education system encompassing all three of the above periods of critical change: early developments from the Koryo dynasty in the 900 s to the end of the Choson dynasty in the early 1900s, Japanese colonization from the early 1900s to 1945 , and post-liberation from 1945 to the present. Specifically, it will address developments that help explain the rapid decrease in education inequality following liberation observed in the education Gini coefficients as discussed above.

\section{Pre-Colonialism \& the Influence of Confucian Culture}

For the past millennium and up to the late 1800 s, the Korean education system was largely derivative of the traditional Chinese model, and its orientation was likewise humanistic and liberal (Kim, 2000, p. 10); technical training for doctors, interpreters, or merchants was considered inferior to literary education in history, art, and philosophy, for example. In 958 during the Koryo dynasty, a civil service examination based on Chinese classical texts and Confucian moral training, much like that developed in China during the Tang dynasty, was established in Korea as a means to recruit qualified men into the government bureaucracy (Seth, 2002, p. 9). Not only did this mark the beginning of a period in which the demand for education grew as a result of the prestigious position of government bureaucrats and associated economic advantages, it established a system of education focused on exam preparation that has been carried to the present in South Korea. Access to this exam and the schools established to prepare students for it, however, was mostly limited during the Chosonn dynasty to the ruling yangban aristocracy, a hereditary class that made up about 15 per cent of the population at most (Sorensen, 1994, p. 12); education among the peasant commoners was considered unnecessary.

Education during this period normally began at sódangs - small, private schools located within villages and taught by local Confucian scholars. Students would spend most of their time committing the Confucian classics to memory or practicing art, calligraphy, or poetry. Success in a sódang would lead to admittance to larger state-run schools called hyanggyo and an opportunity to take the civil service examination (Seth. 2002 , p. 10). A high score on this exam would qualify one for service as a government bureaucrat or a teacher in a Confucian school.

Education in Korea during this period was a mark of advancement and sophistication; indeed, it was one of the only paths of upward social mobility, particularly during the Chosón dynasty from 1392 to 1910 . Status as a Confucian scholar implied moral authority to be respected by all social classes and institutions, including the government itself; this distinction has largely persisted in South Korea today (Seth, 2002, 13). Besides the abstract benefit of moral authority, however, the intentions of Koreans seeking education were likely much the same as those in other countries today; a 


\section{Burt - Korean Education}

successful Confucian education was the surest culturally-approved means of power, prestige, and wealth.

As the Chosonn dynasty began to founder in the late $1800 \mathrm{~s}$ in the face of challenges presented by Western powers and a quickly rising Japan, the government made several desperate attempts at reform to salvage Korean independence. These reforms included abolishing the civil service examination in 1894, allowing for a rapid increase in private educational institutions (Seth, 2002, p. 17), and ultimately permitting the swift decline of traditional Confucian educational institutions. One particularly interesting development in line with this decline is an increased use of hangul, a phonetic alphabet developed indigenously in the 1400s that is easily learned by scholar and peasant alike. Most Confucian scholars derided this writing system as uncultured and persisted in using Chinese characters adapted to the Korean language; only members of the yangban artistocracy, however, had the time and resources necessary to learn this cumbersome writing system. The increasing use of the hangul writing system during the decline of the Confucian education system can be credited with a rapid increase in Korean literacy and the subsequently widening availability of education in the early and mid-1900s.

At this point, one particular aspect of Confucian culture in South Korea's development and its role in the increasingly egalitarian distribution of education in the decades following liberation should be identified. In studies concerning the rapid development of East Asian states such as South Korea, Taiwan, and Japan, one thread is remarkably common: the influence of East Asian values associated with Confucian culture. The concept of East Asian, Confucian values, however, is flawed as the societies of East Asian states vary widely (In, 1999, p. 194) and Confucianism has evolved extensively since its beginnings several millennia ago into an ideology that today encompasses countries with vastly different cultures. Moreover, studies attempting to correlate culture with economic success are subject to observer bias as values associated with a particular culture are easily reconciled with newly observed facts (Sen, 2000). For example, many, especially Koreans themselves, attribute East Asian economic success with Confucian values such as thrift, discipline, and diligence (Berger, 1988; Choi, 1998; Kim, 1994); this same culture, however, was blamed for laziness, apathy, and stagnation in Korea and China previous to the success of the recent decades (Sorensen, 1994, p. 11 : Weber, 1952).

To avoid such problems with a cultural explanation of decreasing inequality in education, this study focuses on the specific fit of a particular value within the problems of a given situation rather than attempting to establish the superiority of a general set of values over another (Sen, 2000). One specific aspect of Confucian culture in South Korea is clear: its emphasis on education. It is not general Confucian ideology or values that must be examined; Confucianism's emphasis on human capital accumulation and the designation of education as one of the only culturally-approved means of upward social and economic mobility, however, help explain the Korean population's generally consistent demand for education. Although this popular demand was stifled by restrictions in class mobility in the Yi dynasty and policies of the Japanese colonial rulers. it eventually drove the education explosion following liberation as former aristocrats and peasants alike sought opportunities in the new, more economically open society of modern South Korea. The wide availability of educational opportunities coupled with 
effective government policies, which will be addressed in detail below, contributed to the increasingly egalitarian distribution of education in South Korea as Confucian ideals drove average people to take advantage of increasing educational opportunity, thus increasing mean years of education in all segments of society while decreasing education inequality as observed in the education Gini coefficient dataset.

\section{Colonization}

With the arrival of imperialist Japan in the late 1800 s and colonial status by 1910 , Korea and its population was largely organized and used to serve the interests of the Japanese empire, and the education system was no exception. The Japanese imperial government saw little benefit in an educated Korean populace and thus limited the ability of Koreans to gain much bevond primary education; fourteen years of education was available to Japanese while Koreans were limited to eight (Seth, 2002, p. 20). The purpose of the limited education that was available to Koreans was "to give the younger generations of Koreans such moral character and general knowledge as will make them loyal subjects of Japan" (Government-General of Chosen, 1911).

Nevertheless, it is in the colonial period that South Korea's modern education system has its roots. The old Confucian system that limited education to upper classes was completely dismantled, primary education was made compulsory and 45 per cent enrollment was achieved by 1945 , a public school system was rapidly expanded, and physical facilities were constructed that would provide a jump-start to the education explosion following liberation in 1945 (McGinn et al., 1980, pp. 81-82). Characteristics of the colonial education system that largely persist to the present include a high degree of centralization, strict, military-like discipline among students, emphasis on moral and academic training, disdain for technical education and occupations, and reliance on competitive entrance examinations.

The limitations placed on Korean educational attainment during the colonial period had two results particularly important to the study of education inequality in South Korea. First, they caused a shortage in the supply of education to Koreans and a pent-up demand that would explode into a rapid expansion following liberation in 1945 (Seth, 2002, 19). As discussed previously, educational opportunities for most Koreans were limited due to class structures in the $\mathrm{Yi}$ dynasty and policies of the Japanese occupational government. With the dismantlement of aristocratic structures by the colonial government and liberation from Japanese policies following World War II, the newly emerging education system was largely open to the entire population; this openness was maintained and enlarged by succeeding governments in South Korea, thus allowing increasing equality in the distribution of education for the next fifty years. Second, the lack of educational opportunity in Korea during colonization led a large portion of the population to seek education and better employment opportunities in other Japanese colonies such as Manchuria or in Japan itself; Cummings (1997, p. 177) estimates that 40 per cent of the adult population of the Korean Peninsula took part in this demographic uprooting. This mass movement of people from Korea and their return following World War II significantly altered previous institutions and routines and provided new opportunities and experiences to millions of Koreans (Seth, 2002, p. 33), thus breaking down previous 


\section{Burt - Korean Education}

barriers and permitting upward social and economic mobility for a much larger segment of the population in the decades following liberation.

\section{Earty Independence \& Economic Takeoff}

Immediately following the Japanese surrender and withdrawal from the peninsula. Koreans ${ }^{\circ}$ pent-up demand for education resulted in an explosion of both private and public educational institutions. As will be explained below, this demand initially lacked direction, but it forced the government to address the issue of education early in the development process and provided the impetus for South Korea to accumulate human and physical capital simultaneously throughout its era of remarkable growth from the 1960s to the 1990s. This contrasts with early development scholars' emphasis on the importance of accumulating physical capital in the initial decades following World War II and the associated policies of many developing countries that led to little or no economic success.

Although the first government under Yi Sŭngman allowed educational institutions to expand without significant limits in response to popular demand, the government under Pak Chŏnghi attempted to limit expansion in the early 1960s and channel demand according to the country's development needs (McGinn et al., 1980, 35). Thus, in sharp contrast to the experience of most developing countries, efforts by the new South Korean government focused more on controlling the growth of education than promoting it. Three characteristics of government attempts to control the expansion of educational in the decades following independence are particularly important to understanding the increasingly equal distribution of education in South Korea: centralization of control of the education system in a strong state, the channeling of educational output to meet the economic needs of the country, and the development of public education.

Liberation from Japanese imperial rule began with division of the peninsula into north and south with a caretaker government under the US military in the south. Despite attempts by this government to establish a decentralized system following World War II, control of education, among other things, was centralized by Yi Sŭngman's government. particularly following a civil war in the early 1950 s and the rise of a rival government in North Korea as a serious threat to South Korean security. Centralized, authoritarian control was maintained until the late 1980s by the governments of Pak Chŏnghi and Chŏn Tuhwan. Although the military dictators of this period used education for political purposes such as instilling lovalty to the leader and demonizing the rival northern neighbor, control by a strong, stable government allowed for the intentional formation of a uniform system open to all segments of society. The Pak government in particular promoted wide access to education to prevent the formation of a poor class that might generate discontent and instability.

Centralized control enabled the government to match educational output to particular economic needs. As mentioned above. Koreans have generally preferred academic over technical education. Mostly unbridled expansion during the government of Yi Sŭngman allowed educational development to take on "a momentum of its own. driven by public demand for schooling and degrees" (Seth, 2002, p. 5) rather than the technical needs of fledging economy. Near the end of the Yi government in 1960, the number of students in 
academic schools grew to 164.492 while enrollment in vocational schools fell to 99,071 (Seth. 2002. p. 112). The result was a large number of unemployed college graduates that could generate more discontent than a poor class; it is estimated at the end of the Yi government in 1960 that 60 per cent of college graduates failed to find employment within three months of graduation (McGinn et al., 1980. p. 38). The Pak government quickly began promoting technical and vocational training and limiting the number of advanced degree holders (Seth 2002, 84). The First Five-Year Educational Development Plan of 1962 decreed cuts in academic subjects, the addition of technical subjects to entrance examinations to encourage greater study in these fields, quotas on the number of post-secondary students, and a goal of a 7:3 ratio of vocational to academic students to be achieved by 1966. Most of these policies were initially ineffective in altering the popular demand for academic education, but the Pak government eventually forced changes through, particularly after its turn to heavy-handed authoritarianism in 1971 (Seth, 2002, pp. 120-139). These policies effectively placed a cap on the ability of a minority of the population to advance in academic education much beyond those of the majority in technical education. A decentralized, democratic government would have found such a task impossible as popular demands ran counter to policies of the Pak government.

The US caretaker government attempted to promote an American-style education system with decentralized control, open access for the entire population to publiclyfunded institutions, and emphasis on all levels of education. Although many facets of the American model were maintained, emphasis on all levels was replaced with a program of development beginning with primary education during the $\mathrm{Yi}$ government and continuing into the Pak government during the 1960s and 1970s (Seth, 2002, p. 75). After achieving universal elementary education by the mid to late 1960 s, the government expanded its focus to nine years of universal education; this was accomplished within a decade, and resources were subsequently shifted to achieve universal secondary education (Seth, 2002, p. 83). Focus was again shifted to tertiary education after universal secondary education was completed in the early 1990s. This sequential devotion of government resources to increasing levels of education is illustrated in Table 3 by the percentage of the government's total education budget devoted to different levels, and Table 4 shows the results of this policy in the rapid, sequential increases in enrollment ratios beginning with primary education. This policy of sequentially promoting education attainment within the entire population rather than an elite class led to the decreases in inequality of the distribution of education observed above. As a result, South Korea has consistently maintained enrollment ratios significantly higher than countries with similar leveis of income per capita (McGinn et al., 1980, p. 62).

The policies of a strong, centralized government from the 1950 s to the 1970 s thus promoted an equal distribution of education by squeezing the vast majority of the South Korean population between a lower educational limit that was gradually raised and an upper limit that restricted access to tertiary education. South Korea was thus able to avoid many of the problems many developing countries are still grappling with today: gaps in the development of an education system and concentration of resources on an elite segment of society (Seth, 2002, p. 4). 


\section{Burt - Korean Education}

\section{Educational Equality and Democracy in South Korea}

As annotation to the above discussion of educational development following liberation, an interesting subject and possible area of future research is the role of an increasingly egalitarian distribution of education in the rise of democratic governance in South Korea. As discussed above, the Confucian culture of Korea designated education as one of the only means of upward social mobility and linked education with moral and institutional authority and duty. Seth (2002, pp. 6-13) points out that this aspect of Korean Confucianism has persisted to the present and that the effective, modern school system developed following liberation unwittingly produced the dissident teachers and students that haunted all three South Korean dictators and helped caused the downfall of two of them.

Table 3: Key Education Indicators - Expenditures on Public Education

\begin{tabular}{|c|c|c|c|c|c|}
\hline & $\begin{array}{c}\text { Public } \\
\text { Education } \\
\text { Expenditure } \\
\text { Year }\end{array}$ & $\begin{array}{c}\text { Public } \\
\text { Education } \\
\text { Expenditure } \\
\text { (\% of govt. } \\
\text { (\%pending) }\end{array}$ & $\begin{array}{c}\text { Primary Ed. } \\
\text { Expenditure } \\
\text { (\% of total } \\
\text { ed. budget) }\end{array}$ & $\begin{array}{c}\text { Secondary } \\
\text { Ed. } \\
\text { Expenditure } \\
\text { (\% of total } \\
\text { ed. budget) }\end{array}$ & $\begin{array}{c}\text { Tertiary Ed. } \\
\text { Expenditure } \\
\text { (\% of total } \\
\text { ed. budget) }\end{array}$ \\
\hline 1970 & 3.51 & -- & -- & 17.78 & 6.37 \\
\hline 1975 & 2.15 & 15.5 & -- & 18.94 & 9.04 \\
\hline 1980 & 3.64 & - & -- & 27.99 & 7.34 \\
\hline 1985 & 4.34 & -- & 37.21 & 29.2 & 8.69 \\
\hline 1990 & 3.33 & 22.43 & 39.51 & 30.45 & 6.62 \\
\hline 1995 & 3.4 & -- & 44.48 & 36.64 & 8.01 \\
\hline 2000 & 3.44 & 11.73 & 41.42 & 37.28 & 13.54 \\
\hline 2002 & 4.22 & 15.48 & 33.96 & 43.41 & 8.07 \\
\hline
\end{tabular}

Source: World Bank Group, 2002

The role of students and instructors of educational institutions in the fall of authoritarianism and the eventual rise of democracy in South Korea is well documented (Seth, 2002; Cummings, 1997; Oberdorfer, 2002). These modern scholars of Korea were essentially exercising the Confucian-implied authority and duty to criticize and demonstrate against the government's immoral, undemocratic practices. Perhaps the establishment of an education system that successfully brought the vast majority of the population to significantly higher levels of education inadvertently generated a large number of people culturally qualified to criticize South Korea's authoritarian leaders. The increasingly equal distribution of education may be linked to the enormous student demonstrations of the 1970s that beleaguered Pak Chonghi and those of the late 1980s that forced Chŏn Tuhwan to step down and thus may be an independent variable in the rise of democracy in South Korea. 
Table 4: Key Education Indicators - Enrollment Rates

\begin{tabular}{|c|c|c|c|}
\hline year & $\begin{array}{c}\text { Gross Enrollment } \\
\text { Rate, Primany } \\
\text { of age group) }\end{array}$ & $\begin{array}{c}\text { Gross Enrollment } \\
\text { Rate, Secondany (\% of } \\
\text { age group) }\end{array}$ & $\begin{array}{c}\text { Gross Enrollment Rate, } \\
\text { Tertiany (\% of age } \\
\text { group) }\end{array}$ \\
\hline 1970 & 103.41 & 41.61 & 7.43 \\
\hline 1975 & 106.86 & 56.35 & 8.8 \\
\hline 1980 & 109.91 & 78.13 & 14.67 \\
\hline 1985 & 97.02 & 91.65 & 34.05 \\
\hline 1990 & 104.94 & 89.83 & 39.1 \\
\hline 1995 & 95.25 & 100.87 & 52.03 \\
\hline 2000 & 100.07 & 94.17 & 77.6 \\
\hline 2002 & 103.86 & 89.84 & 84.73 \\
\hline
\end{tabular}

Source: World Bank Group, 2002

\section{METHODOLOGY}

\section{The Education Gini Coefficient}

The education Gini coefficient, an adaptation of the Gini coefficient originally developed by Corrado Gini to measure income inequality (Gini, 1921), is an effective method of measuring and comparing the distribution of education within a particular geographic area. For the most part, it has been used to compare education inequality at aggregate levels across countries. A single, national indicator of education inequality, however, is relatively useless to governments attempting to establish effective domestic systems of education. Also significant, therefore, is the education Gini coefficient's utility as a statistical comparison of inequality in the distribution of education across the domestic administrative divisions of a particular country and between specific time periods in that country's history. This provides policymakers with a tool to understand the distribution of human capital within the country at different time periods, identify areas with high levels of inequality, and effectively target government policies and programs in specific areas. If the government is unaware of the distribution of education within lower-level -administrative divisions, educational policies can have unintended consequences by benefiting a small segment of the population in areas with high levels of education inequality (Psacharopoulos, 1989; Grootaert, 1994).

This study employs the direct method of measurement of the education Gini coefficient as developed by Thomas, Wang. and Fan (2000; 2001), altered slightly to accommodate the organization of South Korean census data as explained in detail below. The mathematical formula shown in Equation 1 generates a single number bounded by zero and one, zero representing perfect equality and one representing perfect inequality in the distribution of education within a particular population. Thus a coefficient greater than 0.5 , for example, would be considered relatively unequal, and a coefficient less than 0.2 would be considered relatively equal. 


\section{Burt - Korean Education}

(1)

$$
E_{g i n i}=\left(\frac{1}{\mu}\right) \sum_{a=1}^{9} \sum_{b=1}^{a-1} x_{a}\left|z_{a}-z_{b}\right| x_{b}
$$

Equation $l$ consists of three components: $\mu, \mathrm{x}$, and $\mathrm{z} ; \mu$ represents the average years of schooling for the population of analysis, $x$ represents the proportion of the population with $n$ levels of schooling, and $z$ represents the number of years schooling at each level of education.

Although the education Gini coefficient does not address the level of value for the measured variable and fails to specify the location of inequality within the distribution of the measured variable, it provides a single indicator that can be used to compare the distribution of education in one population with that of another. Also, like the original income Gini coefficient, the education Gini coefficient can be graphically illustrated with the Lorenz curve.

\section{The Education Gini Coefficient for South Korean Census Data}

Data from the 1970,1980,1990, and 2000 censuses of the Republic of Korea for the population age six and older were obtained from the Korea National Statistical Office (KNSO) and used to calculate education Gini coefficients for each province (do) and metropolis (tüpyólshi, kwangyǒkshi, and chikalshi) and each county (gun), city (shi), and ward $(g u)$ within them.

In the 1970,1980 , and 1990 census data, levels of education attainment were divided into three categories: "graduated," "not completed," and "never attended." As South Korea has used a 6-3-3-4 system of education since 1961, "graduated primary" was assumed to indicate six years of education, "graduated middle school" nine years, "graduated high school" twelve years, "graduated junior college" fourteen years, and "graduated college or higher" sixteen years. With the exception of the primary level, an incomplete education was assumed to indicate the number of years of education for the next lowest level completed; this is because a partial high school or college education, for example, will have little actual value in South Korea due to the lack of official credentials in the form of a diploma or a degree. Thus "not completed primary" was assumed to indicate three years of education, "not completed middle school" six years, "not completed high school" nine years, "not completed junior college" twelve years, and "not completed college or higher" fourteen years. "Never attended" was assumed to indicate zero years of education. Unlike the 1970 and 1990 census, data in the 1980 census for secondary education was divided into two levels: "general high school" and "vocational high school." These two levels were assumed to indicate the same number of years of schooling for all three categories mentioned above.

* Due to the large amount of data. actual education Gini coefficients for specific administrative divisions for these four years is not available in this article but can be obtained by contacting the author directly. 


\section{Burt - Korean Education}

In the 2000 census data. levels of education attainment were divided into four categories: "graduated," "dropped out," "completed," and "no schooling." Assumptions concerning the first two categories are the same as those of the 1970 census data with the additions that "graduated master"s course" was assumed to indicate eighteen years of education, "graduated doctor's course" twenty years, "dropped out master's course" sixteen years, and "dropped out doctor's course" eighteen years. The "completed" category was available for tertiary education only; it indicates students that finish required coursework for a particular program but fail to complete required theses or pass necessary exams in order to receive a regular degree. Such students often enter specific programs available in certain educational institutions with the intention of completion rather than graduation. Although these students technically attend school for the same duration as graduates. their credentials are not as highly recognized. Thus "completed" was assumed to indicate one year of education less than the "graduated" category for the four tertiary education levels specified in the census data: junior college, university, master"s course, and doctor's course. "No schooling" was assumed to indicate zero years of education.

\section{Findings in the South Korean Education Gini Coefficient Dataset}

The pattern in the data most important to this study is the significant decrease in education inequality in all areas of South Korea from 1970 to 2000 as measured by the education Gini coefficient: this pattern is clearly illustrated in Table 2 and in Figure 1. Although Figure 2 and Figure 3 illustrate continuing high levels of inequality in many areas of the country, the 2000 provincial coefficients indicate a remarkable increase in educational equality overall from 1970 to 2000 . A coefficient of 0.29 , the highest provincial coefficient in South Korea in 2000 , is considered relatively equal compared to most areas of the world. The most significant decreases in most areas occurred between 1970 and 1980. Decreases between 1980 and 1990 and between 1990 and 2000 began slowing down as the Gini coefficients approached zero. 


\section{Burt - Korean Education}

Figure 1: Comparison of Provincial Education Gini Coefficients, 1970-2000*

$\square_{1970 \mathrm{Gini}} \mathbf{D}_{1980 \mathrm{Gini}} \square_{1990 \mathrm{Gini}} \square_{200 J \mathrm{Gini}}$

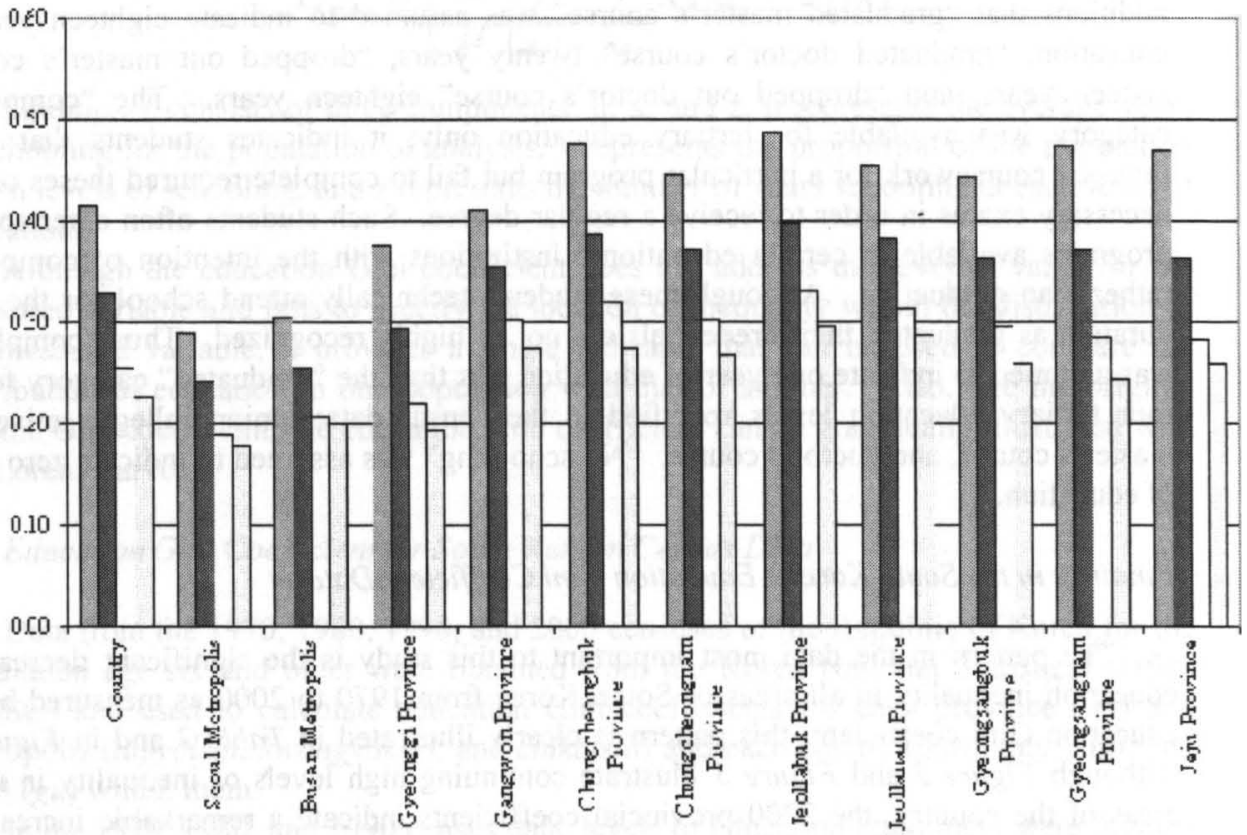

Source: Republic of Korea, 1970; Republic of Korea, 1980; Republic of Korea, 1990; Republic of Korea, 2000; author's calculations and illustration.

* 1990 and 2000 data from some provinces were combined with that of metropolises not existent in 1970 or 1980 in order to maintain continuity of administrative divisions across time and allow consistent comparison.

Although less relevant to the present study, two other patterns deserve mention as they may merit future, more specific research. First, higher levels of education inequality in rural areas as compared to urban areas have persisted to the present; this pattern is shown in Figure 3 and its geographical illustration of the Gini coefficients of major metropolitan areas compared to those of other parts of the country. Second, as shown in Figure 4, higher inequality among females continues in all areas of South Korea's largely male-dominated society. 


\section{Burt - Korean Education}

Figure 2: Geographical Representation of Provincial \& Metropolitan Education Gini Coefficients (2000 data)

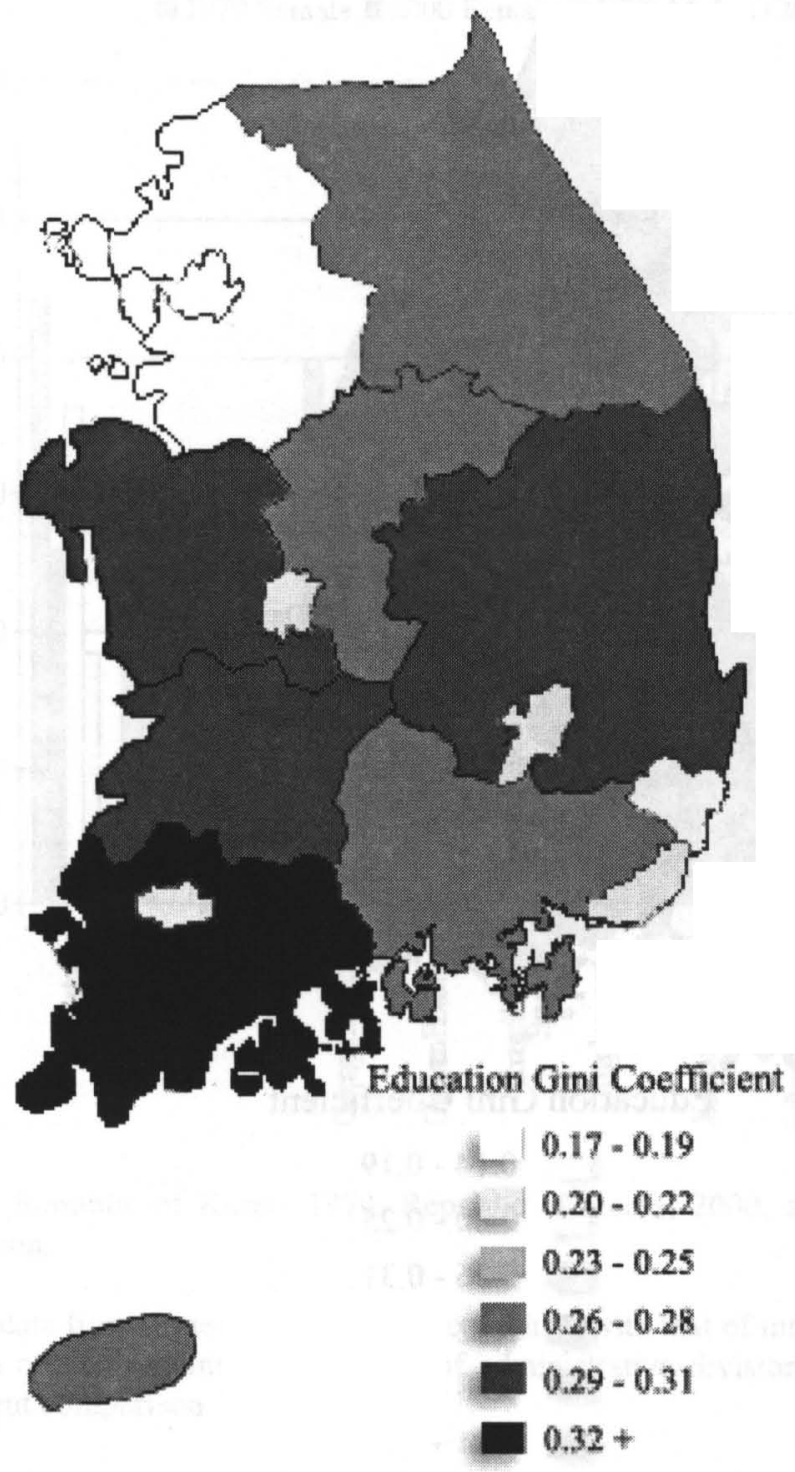

Source: Republic of Korea, 2000; author's calculations and illustration. 


\section{Burt - Korean Education}

Figure 3: Geographical Representation of County, City, \& Ward Education Gini Coefficients (2000 data)
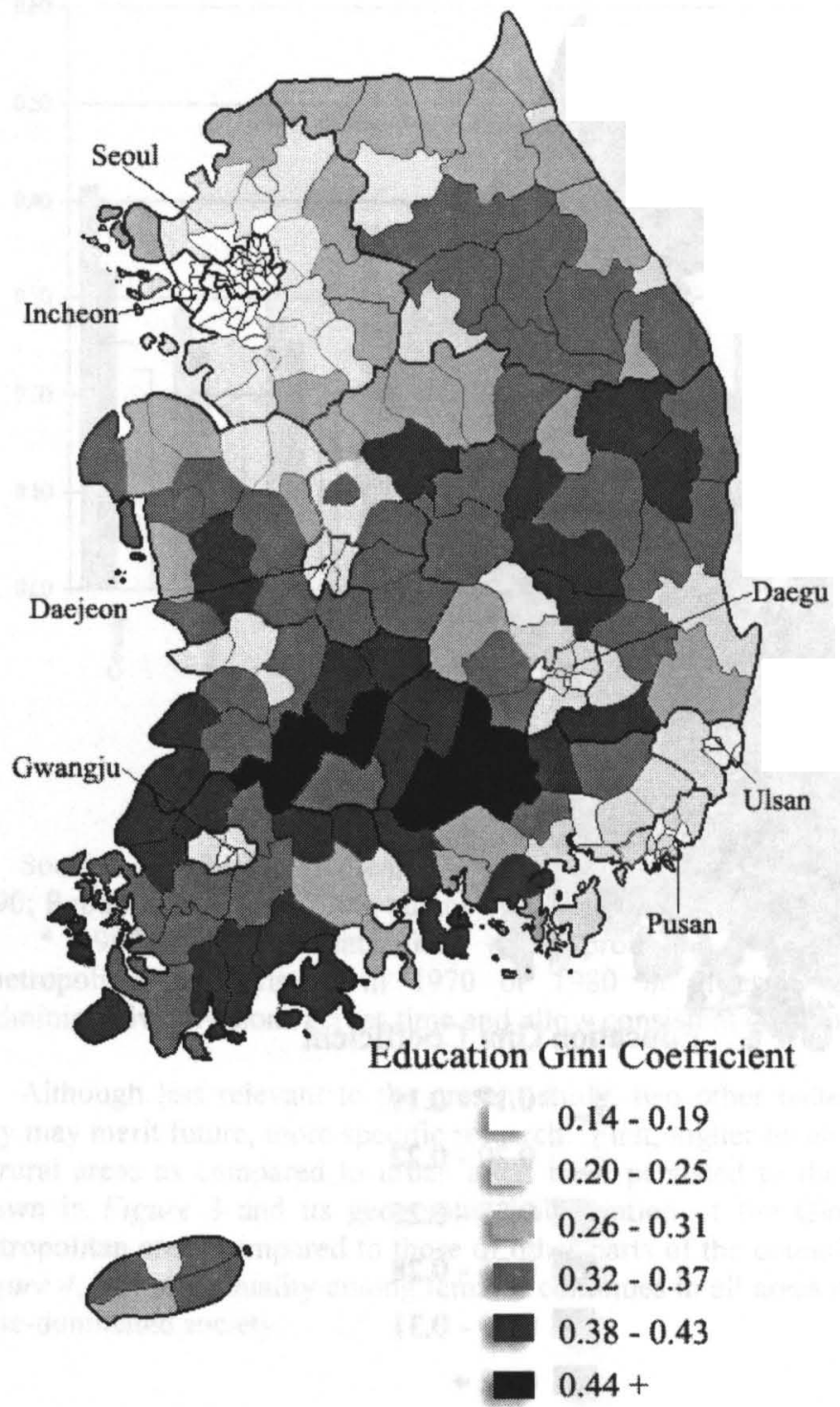

Source: Republic of Korea, 2000; author's calculations and illustration. 


\section{Burt - Korean Education}

Figure 4: Comparison of Female and Male Provincial Gini Coefficients, 1970 and 2000*

$\square 1970$ Female $\square 2000$ Female $\square 1970$ Male $\square 2000$ Male

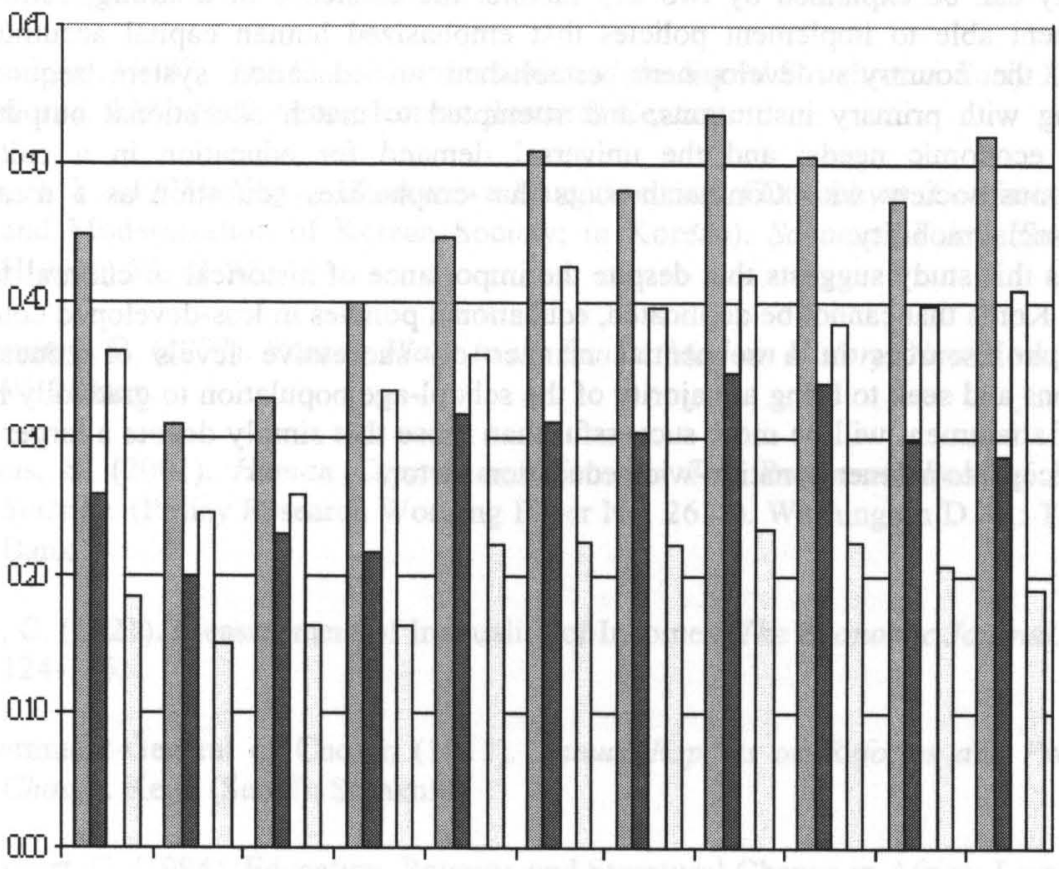

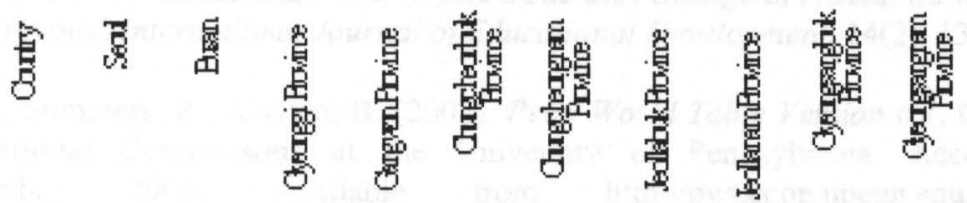

Source: Republic of Korea, 1970; Republic of Korea, 2000; author's calculations and illustration.

* 2000 data from some provinces were combined with that of metropolises not existent in 1970 in order to maintain continuity of administrative divisions across time and allow consistent comparison.

\section{CONCLUSION}

Inequality in the distribution of human capital is one possible reason for the lack of improvement in development prospects of many countries that have shifted resources from investment in physical capital to investment in human capital in the hope of 


\section{Burt - Korean Education}

increasing economic growth (Holsinger, 2005). This paper's documentation of South Korea's remarkable success in increasing equality in the distribution of education during its period of extraordinary economic growth provides a case study for comparison with similar studies in less-developed areas of the world. This remarkable reduction in inequality can be explained by two key factors: the existence of a strong, centralized government able to implement policies that emphasized human capital accumulation early in the country's development, established an education system sequentially beginning with primary institutions, and attempted to match educational output with national economic needs; and the universal demand for education in a culturally homogenous society with Confucian roots that emphasizes education as a means of upward social mobility.

Thus this study suggests that despite the importance of historical or cultural factors in South Korea that cannot be duplicated, educational policies in less-developed countries that focus resources in a sequential manner on successive levels of educational institutions and seek to bring a majority of the school-age population to gradually higher levels of attainment will be more successful than those that simply devote a larger share of resources into a general, nation-wide education sector. 


\section{Burt - Korean Education}

\section{REFERENCES}

Berger, P. L. (1988). An East Asian Development Model? In P. L. Berger \& H. Hsiao (Eds.), In Search of East Asian Development Model (pp. 3-23). New York, NY: Transaction Inc.

Choe, Y. H. (1987). The Civil Examinations and the Social Structure in Early Yi Dynasty Korea, 1392-1600. Seoul: Korean Research Center.

Choi, B. Y. (1998). Yugyo Munhwawa Hanguksahoeui Gundaehwa (Confucian Culture and Modemization of Korean Society; in Korean). Sahoewa Yoksa (Society and History) 53: 61-92.

Cummings, B. (1997). Korea's Place in the Sun: A Modern History. New York, NY: W. W. Norton.

Dessus, S. (2001). Human Capital and Growth: The Recovered Role of Education Systems. (Policy Research Working Paper No. 2632). Washington D. C.: The World Bank.

Gini, C. (1921). Measurement of Inequality of Incomes. The Economic Journal, 31(121), 124-126.

Government-General of Chosen (1911). Annual Reports on Reforms and Progress in Chosen. Keijo (Seoul): Sotokufu.

Grootaert, C. (1994). Education, Poverty, and Structural Change in Africa: Lessons From Cote D'Ivoire. International Journal of Educational Development, 14(2), 131-142.

Heston, A., Summers, R., \& Aten, B. (2002). Penn World Table Version 6.1. Center for International Comparisons at the University of Pennsylvania. Accessed 21 September 2005. Available from http://pwt.econ.upenn.edu/php_site/ pwt61_form.php.

Holsinger, D. B. (2005). Inequality in the Public Provision of Education: Why it Matters. Comparative Education Review, 49(3), 297-310.

In, J. S. (1999). No (Logical) Place for Asian Values in East Asia's Economic Development. Development and Society, 28(2), 191-204.

Kehoe, M. (1949). Higher education in Korea. Far Eastern Quarterly, 8(2), 184-186.

Kim, G. J. (2002). Education Policies and Reform in South Korea. In World Bank, Secondary Education in Africa: Strategies for Renewal (pp. 29-40). Africa Region Human Development Working Paper Series. 


\section{Burt - Korean Education}

Kim, J. C. (2000). Historical Development. In J. Weidman \& N. Park (Eds.), HigherEducation in Korea (pp. 7-53). New York, NY: Falmer Press.

Kim, K. D. (1994). Confucianism and Capitalist Development in East Asia. In L. Sklair (Ed.), Capitalism and Development (pp. 87-106). New York, NY: Routledge.

Lopez, R., Vinod, T., \& Wang, Y. (1998). Addressing the Education Puzzle: The Distribution of Education and Economic Reform. (Policy Research Working Paper No. 2031). Washington, D. C.: The World Bank.

McGinn, N. F., Snodgrass, D.R., Kim, Y. B., Kim, S. B., \& Kim, Q. Y. (1980). Education and Development in Korea. Cambridge, MA: Harvard University Press.

Morris, P. (1996). Asia's Four Little Tigers: A Comparison of the Role of Education in Their Development. Comparative Education, 32(1), 95-109.

Oberdorfer, D. (2001). The Two Koreas: A Contemporary History. New York, NY: Basic Books.

Palais, J. (1975). Politics and Policy in Traditional Korea. Cambridge, MA: Harvard University Press.

Pritchett, L. (2001). Where Has All the Education Gone? World Bank Economic Review, $15(3), 367-391$.

Psacharopoulos, G. (1989). Why Educational Reforms Fail: A Comparative Analysis. International Review of Education, 35, 179-195.

Republic of Korea (1970). 1970 Population Census of the Republic of Korea. Korea National Statistical Office.

Republic of Korea (1980). 1980 Population Census of the Republic of Korea. Korea National Statistical Office.

Republic of Korea (1990). 1990 Population Census of the Republic of Korea. Korea National Statistical Office.

Republic of Korea (2000). 2000 Population Census of the Republic of Korea. Korea National Statistical Office.

Seth, M. J. (2002). Education Fever: Society, Politics, and the Pursuit of Schooling in South Korea. Honolulu, HI: University of Hawai'i Press. 


\section{Burt - Korean Education}

Sen, A. (2000). "Culture and Development." Global Development Network. Accessed 26 December 2005. Available from http://www.gdnet.org/pdf2/gdn_library/ annual_conferences/second_annual_conference/sen.pdf.

Sorensen, C. W. (1994). Success and Education in South Korea. Comparative Education Review, 38(1), 10-35.

Thomas, V., Wang, Y., \& Fan, X. (2000). Measuring Education Inequality: Gini Coefficients of Education (Working Paper Series). Washington, D.C.: The World Bank.

Thomas, V., Wang, Y., \& Fan, X. (2001). Measuring Education Inequality: Gini Coefficients of Education (Policy Research Working Paper No. 2525). Washington, D.C.: The World Bank.

Weber, M. (1952). The Protestant Ethic and the Spirit of Capitalism. London: Allen \& Unwin.

Weil, D. N. (2005). Economic Growth. Boston, MA: Addison-Wesley.

World Bank Group (2002). EdStats. Barro-Lee Data Set. Accessed 29 September 2005. Available from http://devdata.worldbank.org/edstats/td10.asp. 
Tahle 2: Comparison of Edacation Distribution in Prorinces, 1970-2000*

\begin{tabular}{|c|c|c|c|c|c|c|c|c|}
\hline Location & $\begin{array}{c}1970 \text { Afean } \\
\text { lcals Schooling }\end{array}$ & $\begin{array}{l}1070 \text { Gini } \\
\text { Coefficient }\end{array}$ & $\begin{array}{c}1980 \text { Mean } \\
\text { rears Schooling }\end{array}$ & $\begin{array}{l}\text { 1980 Cimi } \\
\text { Coefficient }\end{array}$ & $\begin{array}{c}\text { 1001 Meom } \\
\text { Jears Sohooling }\end{array}$ & $\begin{array}{l}1000 \text { Gimi } \\
\text { sefficicm }\end{array}$ & 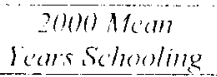 & $\begin{array}{l}2000 \text { (imi } \\
\text { coefficicm }\end{array}$ \\
\hline Nationwide & 5.71 & 0.414 & 7.57 & 0.328 & 9.51 & 0.253 & 10.56 & 0.225 \\
\hline $\begin{array}{l}\text { Seoul } \\
\text { Metropolis }\end{array}$ & 8.21 & 0.288 & 9.56 & 0.241 & 10.94 & 0.189 & 11.70 & 0.178 \\
\hline $\begin{array}{l}\text { Busan } \\
\text { Metropolis }\end{array}$ & 7.31 & 0.304 & 8.57 & 0.253 & 10.11 & 0.205 & 10.78 & 0.200 \\
\hline $\begin{array}{l}\text { Gyeongei } \\
\text { Province }\end{array}$ & 5.82 & 0.376 & 7.74 & 0.292 & 9.90 & 0.219 & 11.01 & 0.193 \\
\hline $\begin{array}{l}\text { Gangwon } \\
\text { Province }\end{array}$ & 5.24 & 0.411 & 6.57 & 0.354 & 8.34 & 0.301 & 9.41 & 0.274 \\
\hline $\begin{array}{l}\text { Chungcheongbuk } \\
\text { Province }\end{array}$ & 4.48 & 0.475 & 6.15 & 0.386 & 8.17 & 0.310 & 051 & 0.272 \\
\hline $\begin{array}{l}\text { Chungcheongmam } \\
\text { Province }\end{array}$ & 4.80 & 0.445 & 6.37 & 0.372 & 8.45 & 0.301 & 9.81 & 0.267 \\
\hline $\begin{array}{l}\text { leollabuk } \\
\text { Province }\end{array}$ & 4.58 & 0.486 & 6.21 & 0.397 & 8.11 & 0.329 & 9.31 & 0.296 \\
\hline $\begin{array}{l}\text { Teollanaln } \\
\text { Province }\end{array}$ & 4.74 & 0.454 & 6.29 & 0.383 & 8.34 & 0.312 & 9.46 & 0.287 \\
\hline $\begin{array}{l}\text { Gyeongsanglouk } \\
\text { Province }\end{array}$ & 5.05 & 0.443 & 6.83 & 0.363 & 8.73 & 0.294 & 9.89 & 0.257 \\
\hline $\begin{array}{l}\text { Gyeongsangmam } \\
\text { lrovince }\end{array}$ & 4.75 & 0.474 & 6.77 & 0.372 & 8.85 & 0.284 & 10.01 & 0.242 \\
\hline $\begin{array}{l}\text { Jeju } \\
\text { Plovince }\end{array}$ & 5.15 & 0.468 & 6.98 & 0.363 & 9.03 & 0.281 & 10.04 & 0.257 \\
\hline
\end{tabular}

Source: Republic of Korea, 1970: Republic of Korea. 1980; Republic of Korea. 1990; Republic of Korea, 2000: author s cakubations.

*1990) and 2000 data from some provinces were combined with that of metropolises not existent in 1970 or 1980 in order (o maintain contimuty of administrative divisions across time and allow consistent comparison. 